\title{
Peningkatan Pengetahuan Masyarakat Mengenai Peran Baitul Maal Wat Tamwil (BMT)
}

\section{Increased Public Knowledge About Role Of Baitul Maal Wat Tamwil (BMT)}

\author{
Nur Izzatish Sholichah ${ }^{1}$ \\ ${ }_{1}^{1}$ Program Studi Perbankan Syariah Fakutas Ekonomi Ekonomi Islam Universitas Djuanda Bogor, Jl Tol \\ Ciawi No.1, Kotak Pos 35 Bogor 16720, email: nurizzatishsholichah@unida.ac.id
}

(Diterima: 25-06-2020; Ditelaah: 15-12-2020; Disetujui: 10-06-2021)

\begin{abstract}
Abstrak
Ditinjau dari agama yang dianut masyarakat Desa Padamulya adalah mayoritas beragama Islam. Dan banyaknya rentenir yang memanfaatkan ketidaktahuan pemilik usaha yang terkendala dengan permodalan untuk menjadi nasabah. Program pengabdian masyarakat ini bertujuan membantu permasalahan yang ada di masyarakat. Metode yang dilakukan adalah dengan metode partisipasi aktif yaitu pendekatan langsung kepada masyarakat melalui sosialisasi dan penyampaian materi tentang pengenalan Lembaga Keuangan Mikro Syariah dan Peran Baitul Maal Wat Tamwil (BMT). Setelah dilakukan sosialisasi respon yang diberikan masyarakat saat dilaksanakan sosialisasi sangat baik dengan ikut berpartisipasi menghadiri dalam kegiatan sosialisasi dan aktif dalam sesi tanya jawab, juga masyarakat lebih mengetahui Ekonomi Syariah dan Lembaga Keuangan Mikro Syariah.
\end{abstract}

Kata kunci: Baitul Maal Wat Tamwil, Ekonomi Syariah, LKMS, Sosialisasi

\begin{abstract}
Reviewed from the religion of the Padamulya Village community, the majority is Muslim. And many loan sharks take advantage of the ignorance of business owners who are constrained by capital to become customers. This community service program aims to help the existing problems in the community. The method used is the active participation method, which is a direct approach to the community through the dissemination and delivery of material about the introduction of Sharia Microfinance Institutions and the Role of Baitul Maal Wat Tamwil (BMT). After the socialization, the response given by the community during the socialization was very good by participating in the socialization activities and being active in the question and answer session, also the public was more aware of Sharia Economics and Sharia Microfinance Institutions.
\end{abstract}

Keywords: Baitul Maal Wat Tamwil, Islamic Economy, LKMS, Socialization

\section{PENDAHULUAN}

Program Pemberdayaan Ekonomi Masyarakat melalui penerapan ilmu ekonomi Islam merupakan salah satu bentuk implementasi dari pengabdian kepada masyarakat (PKM). Bentuk pengabdian tersebut dilaksanakan dengan cara menerapkan salah satu ilmu pengetahuan tentang ekonomi Islam salah satunya melalui program "Sosialisasi Ekonomi Syariah", sehingga mahasiswa dapat mengaplikasikan ilmu pengetahuan yang telah dikaji di dunia akademis, juga manfaat yang timbul dapat dirasakan oleh masyarakat.

Pada pelaksanaan pengabdian masyarakat di Desa Padamulya yang memiliki banyak potensi dijadikan usaha berasal dari penjualan produk, pertanian, peternakan, dan lain sebagainya yang mengahasilkan sumber pendapatan. Namun, masyarakat pun sering mengalami kendala dalam masalah permodalan untuk mengembangkan usahanya 
sehingga masyarakat terpaksa melakukan pinjaman modal kepada rentenir. Sehingga program dari pengabdian kepada masyarakat di harapkan dapat mengetahui peran lembaga keuangan mikro syariah (LKMS) salah satunya adalah Baitul Maal Wat Tamwil (BMT).

Banyaknya masyarakat yang masih menggunakan bank keliling atau rentenir dalam membiayai usahanya dikarenakan tidak adanya lembaga keuangan mikro syariah sebagai lembaga yang dapat membantu masyarakat dalam masalah permodalan untuk mengembangkan usahanya dengan prinsip syariah. Selain itu, kondisi daerah yang memiliki cukup sulit dijangkau menjadi salah satu faktor terbatasnya pengetahuan ekonomi islam, minimnya kajian-kajian dengan pemateri yang ahli dalam membahas mengenai ekonomi islam khususnya lembaga keuangan mikro syariah yang mengakibatkan masih rendahnya pengetahuan masyarakat terhadap ekonomi syariah. Oleh karena itu, pengabdian masyarakat ini perlu dilaksanakan dalam rangka meningkatkan pengetahuan masyarakat terhadap ekonomi syariah, salah satunya dengan metode sosialisasi. Diharapkan dengan adanya sosialisasi dapat meningkatkan pengetahuan dan kesadaraan masyarakat untuk menggunakan LKMS dalam kegiatan perekonomian secara optimal.

Dalam sistem ekonomi syariah menekankan konsep manfaat pada kegiatan ekonomi yang lebih luas, bukan hanya pada manfaat di setiap akhir kegiatan, melainkan pada setiap proses transaksi. (Hidayah dan Kartini, 2016: 75). Keberadaan lembaga keuangan syariah merupakan sistem yang telah lama diharapkan oleh sebagian besar masyarakat Indonesia, terutama umat Islam Indonesia. Umat Islam Indonesia merindukan layanan jasa keuangan dan perbankan yang sesuai dengan syariat Islam, khususnya berkaitan dengan pelanggaran praktik riba, jauh dari kegiatan yang spekulatif yang serupa dengan perjudian, ketidakjelasan, pelanggaran prinsip keadilan dalam bertransaksi, serta keharusan penyaluran pembiayaan dan investasi pada kegiatan usaha yang etis dan benar secara syariah. Hadirnya sistem ekonomi islam di pedesaan akan mampu menjadi alternative dalam memperbaiki kehidupan masyarakat pedesaan yang mayoritas berada dalam jerat kemiskinan. (Kusmanto,2014:232).

\section{METODE PELAKSANAAN}

Pelaksanaan kegiatan dimulai dengan persiapan perizinan dan survey lokasi awal melihat kondisi kesiapan responden di lapangan dan sosialisasi, selanjutnya melakukan penyusunan materi. Responden dalam kegiatan ini terdiri atas Ibu-ibu pengajian di Kp. Lingkungsari, seluruh yang hadir dalam kegiatan sosialisasi berjumlah 43 orang. Pelaksanaan kegiatan ini menggunakan metode Pendekatan Orang Dewasa (POD) yang dilakukan secara partisipasi aktif dengan metode ceramah dan adanya sesi tanya jawab, untuk peningkatan pengetahuan tentang Peran Baitul Maal Wat Tamwil (BMT). 


\section{HASIL \& PEMBAHASAN}

Kegiatan sosialisasi ini dihadiri oleh 43 Orang. Kegiatan ini dilakukan di Masjid Darussalam Dusun Lingkungsari Desa Padamulya Pukul 13.00 WIB. Materi yang disampaikan pada kegiatan sosialisasi ini adalah Peran Baitul Maal Wat Tamwil (BMT). Adapun hasil dari kegiatan sosialisasi Peran BMT adalah sebagai berikut:

a. Setelah dilakukan sosialisasi dihadapan masyarakat (Ibu-ibu) tentang ekonomi syariah telah ada pengetahuan baru terhadap materi disampaikan meskipun memang belum pada tahap memahami yang secara rinci.

b. Meningkatnya pengetahuan masyarakat mengenai Peran BMT diawali dengan pengenalan terhadap LKMS, dilanjutkan dengan perbedaan antara LKMS dengan Lembaga Keuangan Konvensional, serta memberi pemahaman terhadap peran BMT sebagai lembaga keuagan mikro syariah yang dapat membantu masyarakat untuk dapat mengembangkan usaha atau dengan menghimpun dana sesuai dengan prinsip syariah.

Pelaksanaan Kegiatan

Program sosialisasi ini dilaksanakan 1 (satu) kali di Masjid Darussalam pada tanggal 23 Agustus 2019 jam 13.00 yaitu disaat pengajian rutin yang diadakan oleh ibuibu di Kp. Lingkungsari. Kegiatan sosialisasi ini dilaksanakan dengan pemaparan materi kepada Ibu-ibu pengajian Majlis Ta'lim Darussalam. Jumlah masyarakat yang hadir dalam kegiatan Sosialisasi Peran BMT ini ada 43 Orang. Adapun materi yang disampaikan yaitu memperkenalkan Lembaga Keuangan Mikro Syariah, perbandingan antara LKMS dengan Lembaga Keuangan Konvensional dan Peran dari BMT.

\section{Sosialisasi Peran BMT}

Sosialisasi ini dimaksudkan supaya masyarakat Kp. Lingkungsari dapat mengetahui Peran BMT dalam mengembangkan usaha. Dalam sosialisasi tentunya harus melalui tahapan-tahapan, yaitu memahami kondisi dan permasalahan yang ada dimasyarakat dan perlu adanya pemateri yang telah menguasai materi yang ingin disampaikan tentang LKMS terutama peran Baitu Maal Wat Tamwil sebagai lembaga keuangan mikro. Kemudian setelah mempersiapkan materi dilanjut dengan melakukan perizinan serta menyusun acara sosialisasi serta mempersiapkan sarana yang diperlukan untuk melaksanakan kegiatan sosialisasi Peran BMT.

\section{Evaluasi dan Monitoring}

Indikator keberhasilan kegiatan ini adalah jumlah dan keseriusan dari masyarakat mengikuti partisipasi dalam kegiatan sosialisasi. Sebagian besar peserta aktif mengikuti seluruh kegiatan dari awal pemaparan sosialisasi. Pendekatan dengan cara bertatap muka langsung memberi kesempatan yang lebih banyak untuk memberikan informasi mengenai Peran BMT kepada masyarakat.

Adapun indikator ketidakcapaian dari kegiatan sosialisasi ini yaitu pemberian materi sosialisasi mengenai Peran BMT baru sampai tahap pengenalan belum sampai kepada materi yang mendalam mengenai Peran BMT. Tidak terealisasikan acara 
sosialisasi yang dilaksanakan dalam bentuk seminar ini karena kegiatan sosialisasi lebih efektif jika dilakukan ketika pengajian karena jadwal pengajian sudah pasti dan banyaknya masyarakat yang rutin hadir dalam pengajian dan kegiatan sosialisasi tidak dilakukan lebih dari 1 kali, karena keterbatasan waktu yang tidak memungkinkan. Adanya Evaluasi berhubungan dengan hasil informasi tentang nilai serta memberikan gambaran tentang manfaat suatu kebijakan/program.

Indikator Hasil dan Manfaat

Hasil dan manfaat dari sosialisasi ini antara lain para masyarakat sudah memiliki peningkatan pengetahuan tentang Peran BMT. Pemaparan materi melalui metode ceramah dan adanya sesi tanya jawab. Setelah selesai pemaparan materi beberapa masyarakat antusias dengan mengajukan pertanyaan terkait BMT seperti:

1. Apa saja akad yang digunakan di BMT khususnya untuk pembiayaan?

2. Apabila usaha tidak mendapatkan jumlah keuntungan yang sama setiap bulannya.

3. Bagaimana menghitung bagi hasil yang nanti akan dibayarkan kepada BMT?

Dengan pertanyaan yang diajukan oleh masyarakat menjadi salah satu indikator meningkatnya pengetahuan masyarakat mengenai peran BMT.

Masalah Yang Dihadapi

Masalah yang dihadapi dari kegiatan ini adalah kurang memadainya fasilitas pendukung dalam berjalannya kegiatan sosialisasi seperti dari segi sarana prasarana, kemudian masih banyaknya masyarakat yang mempunyai kegiatan yang lain seperti bertani, sehingga belum dapat mengikuti kegiatan sosialisasi. Dan disisi lain masih kurangnya pemateri yang ahli dalam membimbing masyarakat untuk lebih memahami peran dari BMT. Masih banyaknya masyarakat yang menjadi nasabah Bank Keliling atau rentenir sehingga perlu kehati-hatian dalam penyampaian materi.

\section{KESIMPULAN}

Adapun hasil dari kegiatan sosialisasi Peran Baitul Maal Wat Tamwil (BMT) yaitu:

1. Adanya pemaparan materi yang disampaikan pada kegiatan sosialisasi ini adalah tentang pengenalan LKMS, Perbandingan Lembaga Keuangan Konvensional dengan LKMS, penjelasan dari Baitul Maal Wat Tamwil, peran BMT di masyarakat dan peran BMT untuk pelaku usaha.

2. Meningkatnya pengetahuan masyarakat tentang peran BMT yang dapat dilihat dari respon yang baik dari masyarakat dengan adanya pertanyaan yang diajukan. Hal ini dilaksanakan untuk memberikan pengetahuan kepada masyarakat tentang BMT sebagai lembaga keuangan yang sesuai dengan prinsip-prinsip syariah.

3. Selain hasil berupa non fisik, ada juga hasil non-fisik (draft) dalam program Sosialisasi Ekonomi Syariah mengenai Peran Baitul Maal Wat Tamwil (BMT) yaitu dalam berbentuk modul yang berjudul "PERAN BAITUL MAAL WAT TAMWIL (BMT)". 


\section{DAFTAR PUSTAKA}

Hidayah, A. N., \& Kartini, I. A. (2016). Peranan Bank dalam Sosialisasi dan Edukasi Masyarakat tentang Kemanfaatan Produk dan Jasa Perbankan Syariah. Jurnal Kosmik Hukum, Vol. 16 No. 1, Pp. 75

Kusmanto, Y. T. (2014). Pengembangan Ekonomi Islam Berbasis Kependudukan di Perdesaan. Jurnal Ilmu Dakwah, Vol. 34 No. 2, Pp. 232.

Paramita, M., Muhlisin, H., \& Palawa , I. (2017). Peningkatan Ekonomi Masyarakat melalui Pemanfaatan Sumber Daya Lokal di Desa Kabandungan Kabupaten Sukabumi. Laporan Akhir Ipteks Bagi Masyarakat (IbM). 